\title{
The deaf cannot see: An accumulation of blindness and deafness as combined theme in Isaiah $\mathbf{4 2}$ and 43
}

\author{
Author: \\ Chris van der Walt ${ }^{1}$ \\ Affiliation: \\ ${ }^{1}$ Faculty of Theology, \\ North-West University, \\ Potchefstroom Campus, \\ South Africa \\ Correspondence to: \\ Chris van der Walt \\ Email: \\ chris.vanderwalt@nwu.ac.za \\ Postal address: \\ PO Box 19498, Noordbrug \\ 2522, South Africa \\ Dates: \\ Received: 03 Oct. 2013 \\ Accepted: 17 Jan. 2014 \\ Published: 06 June 2014 \\ How to cite this article: \\ Van der Walt, C., 2014, \\ 'The deaf cannot see: An \\ accumulation of blindness \\ and deafness as combined \\ theme in Isaiah 42 and 43', In \\ die Skriflig 48(2), Art. \#1764, \\ 6 pages. http://dx.doi. \\ org/10.4102/ids.v48i2.1764

\section{Copyright:} \\ C 2014. The Authors. \\ Licensee: AOSIS \\ OpenJournals. This work \\ is licensed under the \\ Creative Commons \\ Attribution License.
}

Read online:

Scan this QR code with your smart phone or mobile device to read online.
In the Bible the words blind and deaf occur nine times in the same sentence. An accumulation of such sentences is found in Isaiah 42 and 43, where it occurs three times (Is 42:18, 19; 43:8). Blindness is also mentioned in two further sentences in these chapters. Not only is it stated that the people of God is blind, but Israel also accuses Yahweh that their way is hidden from him (Is 40:27). It is because of this accusation, pertaining to an alleged blindness on Yahweh's side, that the question of hearing is raised. He answers to this accusation in the heavenly court with the questions 'Do you not know? Have you not heard?' From there on God makes it clear that seeing is dependent on hearing. In a heavenly court of law, the wrong perception that God's people had about the exile was put straight and a new beginning for the exiles was subsequently made. The theme of blind- and deafness is thereby continued from Isaiah 1 and 6 in the verdict in the heavenly court in Isaiah 43, where it became clear that the cure for the spiritual blindness of God's people is not related to their eyes, but to their ears.

Die dowes kan nie sien nie: ' $n$ Opeenhoping van blind- en doofheid as saamgestelde tema in Jesaja 42 en 43. In die Bybel kom die woorde blind en doof nege keer saam in dieselfde sin voor. 'n Opeenhoping van hierdie sinne word in Jesaja 42 en 43 aangetref waar dit drie maal voorkom (Jes 42:18, 19; 43:8). Blindheid word ook in twee verdere sinne in hierdie hoofstukke genoem. Nie alleen word dit gestel dat die volk van God blind is nie, maar die volk beskuldig God dat Hy nie raaksien wat van hulle word nie (Jes 40:27). In die hemelse hof antwoord God op hierdie beskuldiging met die vrae 'Weet julle nie? Het julle nie gehoor nie?' Van daardie punt af maak God dit duidelik dat sien van hoor afhanklik is. Hierdie verkeerde persepsie van die volk oor God se sogenaamde blindheid vir hulle welstand tydens die ballingskap, word reggestel en 'n nuwe begin word gemaak. Die tema van blind- en doofheid word sodoende uit Jesaja 1 en 6 voortgesit in die uitspraak wat in die hemelse hof gemaak word (Jes 43). Daar word dit duidelik dat die oplossing vir die geestelike blindheid van die volk nie verband hou met hulle sig nie, maar met hulle gehoor.

\section{Introduction}

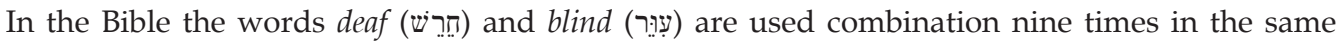
sentence. Seven of these occurrences are in the Old Testament and two in the New Testament (Mt 11:5; Lk 7:22). Of the seven occurrences in the Old Testament, two are found in the Pentateuch (Ex 4:11; Lv 19:14), and the other five in the book of Isaiah (Is 29:18; 35:5; 42:18, 19; 43:8). Three of these five occurrences are found in just two chapters (Is 42:18, 19; 43:8).

It is remarkable that blindness and deafness are associated with each other repeatedly in Isaiah only. Even more remarkable is the accumulation thereof in Isaiah 42 and 43 . Whilst 'blind' and 'deaf' are directly linked in the sentences mentioned, there are further occasions within the direct context of Isaiah 42-43 where the notions of hearing and seeing are associated with one another. An example can be found in Isaiah 40:27-28 where Jacob/Israel laments Yahweh's alleged inability to see their suffering when he says: 'My way is hidden from the Lord; my cause is disregarded by my God', upon which Yahweh responds with the question: 'Have you not heard?'

Against the abovementioned background, questions arise about the theological significance of the unusual combination of blindness and deafness in the book of Isaiah and the concentration thereof in a small portion of the book. In order to shed light on the matter, the article will be developed as follows: firstly, exegesis of Isaiah 1 and 6 will establish the setting of the scene for the rest of the book (Beyer 2007:38; Goldingay 2005:5). This will be done against the backdrop of Deuteronomy, where the treaty between Yahweh and Israel is noted. Lastly, the exegesis of the proceedings of the heavenly court in Isaiah 40-43 will be looked at in order to explain the reason for the accumulation of 'blind' and 'deaf' related ideas in that portion of Isaiah. 
Even though there are many questions about this topic and given the fact that Clements (1985:101) identified blindness and deafness as a recurring theme in the book of Isaiah, only one publication on the topic could be found: the book of Evans (1989). Research on this recurring theme is therefore necessary.

\section{Orientation}

In this article the book of Isaiah (1-66) will be treated as a theological unity, despite the fact that there is an ongoing discussion about its unity. This is based on the growing consensus in biblical scholarship during the past few years that Isaiah should be read and studied as a unity - a complex one, no doubt, but a unity nonetheless in both form and content (Childs 2001:3; Williamson 2009:21; Dekker 2012:41). Discussion about this matter will not be included in this article, because it is extensively covered in other scholarly material. ${ }^{1}$

\section{Isaiah 1: The first scene sets the atmosphere for the rest of the book}

The book of Isaiah opens in much the same way as other major prophetic books, except that the actual calling of the prophet is only found later in the book, namely in chapter 6 (Harman 2011:79). The first sentence of Isaiah 1 gives a time indication of when the prophetic book of Isaiah commenced, that is, during the reigns of Uzziah, Jotham, Ahaz and Hezekiah, kings of Judah. These kings reigned from 740 686 BCE (Motyer 1993:18). This means that, though Isaiah's prophetic activity was focused predominantly against Judah, it started even before the exile of the Northern kingdom, which happened in 722 BCE as Uzziah died ca. 740 BCE. This had the implication that Isaiah could make use of the situation of the Northern tribes as an example in his own prophetic activity directed against Judah (Is 9:8; Matthews 2012:109).

Immediately after setting the historic situation in which the prophecy of Isaiah, son of Amos, commenced, Yahweh, in Isaiah 1:2, calls the heavenly bodies as well as the earth to hear. This exhortation to hear relates to the institution of the covenant between Yahweh and Israel, which is recorded in the book of Deuteronomy (Bartholomew \& Goheen 2006:53). In correspondence with the elements of the Ancient Near Eastern vassal treaties, a list of witnesses was included in the treaty (Hill 2009:167). When establishing the treaty, the Lord called heaven and earth as witnesses as can be seen from Deuteronomy where he said:

This day I call heaven and earth as witnesses against you that I have set before you life and death, blessings and curses. Now choose life, so that you and your children may live. (Dt 30:19)

Not only were witnesses called, but they were called for a specific reason (Kaiser 1996:12). In similar ancient Near

1.For further reading on this matter, B.S. Childs's Introduction to the Old Testament as Scripture (1983:316-338) can be consulted. He did groundbreaking work on the field of the canonical approach to the Old Testament. For a more recent oversight of the discussion, Beyer's Encountering the book of Isaiah (2007:153-159) can be read.
Eastern vassal treaties, the witnesses were usually the gods, but because of Israel's monotheistic faith, that appeal should be made to what Yahweh created - hence heaven and earth are called upon, because it would endure into future ages. Such appeal to creation is attested elsewhere in the Old Testament when the Lord enters into some kind of formal legal encounter with his people (cf. Dt 4:26; 31:28; 32:1; Is 1:2; Mi 1:2; Merrill 1994:393). According to Block (2011:164), Deuteronomy 30:19 and Isaiah 1:2 are thematically linked on the subject of the heavens and the earth as being witnesses in a prophetic lawsuit.

When the stipulations of the treaty needed to be enforced in future, the heaven and earth would be called upon to formally testify. This reflects the situation in Isaiah 1 and is consequently the reason for the witnesses being called:

Hear, O heavens! Listen, O earth! For the LORD has spoken: 'I reared children and brought them up, but they have rebelled against me. The ox knows his master, the donkey his owner's manger, but Israel does not know, my people do not understand.' (Is 1:3)

In this statement, the benevolence of Yahweh towards his people is stated as well as their lack of understanding as a response to the stipulations of the treaty Yahweh made with them. The seriousness of this statement made by Yahweh should be seen in accordance with the Hebrew understanding of fatherhood, where the role of the father is not just that of begetting a son, but where he also fulfils a nurturing role (Oswalt 1986:86).

The history of Israel depicted how they became corrupt and did not adhere to the covenant. Therefore, the curse clause in the covenant would come into play - as can be seen from Isaiah 1:4 onwards (Motyer 1993:43). The case to be considered and resolved in the heavenly court of law is that the people of Yahweh transgressed the stipulations of the covenant and they kept on doing so (Helberg 2011:233). According to Jeremiah 7:25 this had happened since they left Egypt and although Yahweh sent his prophets day after day, his people did not listen. Therefore, the heavens and the earth should hear that Israel have not heard, and because the people of God have not heard, they had no understanding.

\section{Isaiah 6: The calling and commission of the prophet}

From chapter 1 we move to chapter 6 where the actual calling and commission of Isaiah is described. In this experience that Isaiah had, he came deeply under the impression of God's holy presence (Kaiser 1996:118). After he was cleansed of his sins, he received a commission from God to fulfil a well-defined task (Beyer 2007:60). The task that Isaiah had to fulfil is described in Isaiah 6:9-10, where the Lord commands: 'Go and tell this people: "Be ever hearing, but never understanding; be ever seeing, but never perceiving."' Hearing and understanding are thus brought in relation with one another in a very intense construction. The syntactical construction of the two imperatives ('hear'/שמעו' and 
'see'/ראה), plus the two infinitive absolutes ('hearing' / שמוע and 'seeing'/ראה) intensifies the action of the verbs and thus stresses the continuation of not hearing, not seeing and not understanding (Davidson 1902:119). Therefore, what Israel was accused of in Isaiah 1 is reiterated and gets a new dimension in Isaiah 6. In Isaiah 1, it is apparent that God's people lacked understanding. In Isaiah 6, the prophet gets the command to bring the people of God the message that they would continually lack hearing, seeing and understanding (בין). With people or an individual as subject, בין frequently deals with attention to Yahweh's activity in nature and history (Jenni \& Westermann 1997:231). What is meant, therefore, is that the people of Yahweh will be spiritually insensitive for what he is doing in and through the history of Israel. Even though they will go on to hear and see, those experiences will not bring them understanding or knowledge. They will thus not be able to see the reason for the exile, which is introduced in Isaiah 6 (Harman 2011:84, 87).

That inability will subsequently be unaltered until the Lord has removed the inhabitants from the land. This removal from the land is in accordance with the curses announced in Deuteronomy 28:32-63, where it is stipulated that God's people would be uprooted from the land they were entering to possess if they were unfaithful to the covenant. Just as it pleased the Lord to make them prosper and increase in number, so it will please him to ruin and destroy them. Isaiah's commission is therefore an appointment to pronounce the sentence of the heavenly judicial court to a people who transgressed the stipulations of the treaty. This announcement came true when first the Northern Kingdom was exiled in $722 \mathrm{BCE}$, followed by the onset of the exile of the Southern Kingdom 125 years later in 597 BCE (Becking 2011:152).

To condense thus far, Isaiah is called to a people who transgressed the stipulations of the covenant on a continuous basis. This was the result of them not listening to the prophets. Because of the rejection of the prophets and their messages, Israel had no understanding of God's deeds in history - and Isaiah's message would reinforce that. Judah had the opportunity to learn from the Northern Kingdom and/or Ephraim's exile, but because they did not understand what Yahweh was doing, they underwent the same fate.

\section{Isaiah 40-43: God makes a new beginning despite a desperate situation}

The setting of Isaiah 40-43 is, like Isaiah 6, the heavenly court where God is again addressing those present, and those present address one another. The main difference between the situations of those being addressed in chapter 6 and those in chapters $40-43$, is that in chapter 6 destruction was still to follow, whilst destruction has now come to an end (Is 40:1-2). Inherently, this situation fits the context of the Babylonian exile (Goldingay 2005:6).

\section{Isaiah 40:27-28}

One of the issues being addressed in the heavenly court was whether God still cared about Israel. In a prophetic disputation, questions are put forward before replying to it (Goldingay 2005:66). In Isaiah 40:27, God questions Jacob/ Israel about an allegation made against him: 'Why do you say, O Jacob, and complain, O Israel, "My way is hidden

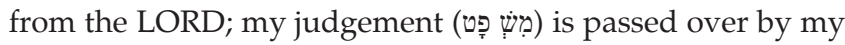

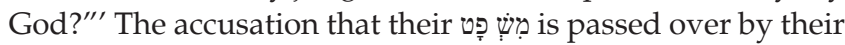
God is of importance. The most frequent use of פִ̣ פִ פִ in the prophetic literature is in connection with a breach of justice, with the result that the Israelites suffered at the hand of their corrupt leaders (Liedke 1976:1001). As a result of this, the Lord himself was expected to step in to bring judgement on behalf of his own people. This time it did not happen, and therefore God's exiled people came to their own conclusions. They perceived it as apparent inactivity on the Lord's side, resulting in a lack of justice being done to them, and therefore the community fell apart (Balentine 2011:349). The exilic community felt that if their פִשֶ פִ was taken care of by Yahweh, they would not suffer and that the damaged order in their community would be restored. Instead of order in the community, there was not only complete disorder, but also suspension of the cultic activities in Jerusalem because of the Babylonian exile and the destruction of the temple in Jerusalem (Van der Walt 2004:98). They wanted God to intervene on their behalf, but as far as their reasoning was concerned, he did nothing. According to their understanding, God did nothing about their situation either because the gods of Babylon had triumphed over Yahweh, or alternately because he was indifferent to their situation. The reality, however, was quite different to what they thought (Brueggemann 1997:20).

It was that wrong perception that needed addressing before restitution could take place. The first movement towards amends was made in Isaiah 40 when Yahweh asked:

Do you not know? Have you not heard? The Lord is the everlasting God, the Creator of the ends of the earth. He will not grow tired or weary, and his understanding no one can fathom. (Is 40:28)

The fact that the first rhetorical question begins with implies that the hearers should already know the answer (cf. Is 40:21). Past experience, teachings from the Torah and prophetic proclamations adequately explain who God is and how he deals with his people (Smith 2009:121). That is also the reason why they are addressed as Jacob or Israel. It is reminiscent of their eponymous ancestor to whom he made himself known a very long time ago when Jacob struggled with God (cf. Gn 32:28; Knight 1984:24).

What happened to Judah in the exile should not have turned their thoughts to God as being the reason for their ordeal, but they should rather have turned their thoughts to themselves and their broken relationship with God. Therefore, the rhetorical questions are about knowledge they should have had and about what they should have heard. What they 
should have known, because they heard it being proclaimed to them is that God is bound neither by time, because he is eternal, nor geographically bound, because he is the creator of everything (Motyer 1993:307). The lament of Israel about God disregarding their right was based on the perception that he was no longer actively involved with them. A further perception was that, because they were no longer present in the Promised Land and far away from the temple in Jerusalem, they were out of reach of God. When the land and the cultic activities at the temple ceased, their perception was that the relationship with Yahweh was subsequently lost (Van der Walt 2004:98). Judah perceived it as if God had abandoned them. What was unfathomable to them (the people of Yahweh) was that Yahweh brought the exile over them. They expected that in 'the day of the Lord' (יום ליהוה), he would bring destruction to their enemies, but then it brought judgement and destruction (cf. Am 5:18) first to Israel and later also to Judah (Helberg 2011:224). This resulted in the emotion 'how could our God do this [the preamble to the exile, and the exile itself] to us'. They were of the opinion that their formal keeping of the rituals of the cult safeguarded them from such a calamity as exile (Jr 7:1-3). In contrast to their expectation, God said: 'Your cultic actions were meaningless and detestable to me' (Is 1:11-14). As the actions of God's people were detestable to him, he sent prophets to call them verbally and visually to repentance, but they did not rectify their evil ways. No one turned around and no one considered that God was justified in exiling them as the last form of discipline in order to magnify his law (Childs 2001:334). They did not perceive the exilic history that Yahweh was unfolding around them in the context of justice being done to them (Balentine 2011:349). The lack of understanding, which Isaiah 1 mentioned, was still present as can be seen from the way they attempted to make sense from the exile by accusing Yahweh, suggesting his defeat and adopting other gods (Is 41:24). Therefore, they needed to receive a new proclamation of the truth. It is obvious that even though they heard the truth in the past, they did not internalise it. This time the proclamation would be different. They received from the Lord's hand double punishment for their sins and now was the time for comfort and a new beginning (cf. Is 40:1, 2).

It can therefore be said that God made it clear that he is neither inactive nor absent. What is certain is that no issue of justice was, or ever will, be overlooked by God. The answer to the question about Jacob or Israel's suffering is therefore not: 'God is inactive, therefore are we suffering.' The answer lies elsewhere and it pertains to something they should have heard. A statement of truth that was actually proclaimed to them perfectly and in such a way that nothing could be said in argument that they have not heard before.

\section{Isaiah 42:18-25}

The hearer who did not pick up the hints of confrontation between the lines in Isaiah 40:1 to 42:17 might be surprised by the outspoken confrontational contents of Isaiah 42:18-25. However, the significant motif of blindness was already introduced in verses 7 and 16. Yahweh will take blindness away and bring people to light again (Goldingay 2005:178). In order to take blindness away, they should hear.

The stem שמע occurs four times in this pericope (Is 42:18, 20, 23, 24), thus emphasising it. The verbs שמע recall the similar verbs in Isaiah 6:9-10 - especially שמעו in verse 18, which is also an imperative. Verse 20 also recalls Isaiah 6:910. The exhortation 'to hear' indicates that it is time for Israel to be made newly aware of what Yahweh has done in recent times (Evans 1989:44).

Isaiah 42:18 and further picks up another theme from the earlier chapters, and that is the theme of the 'servant of the Lord' (עבד יהוה; Is 41:8-9, 42:1). Israel is firstly depicted as the servant and secondly as blind (Childs 2001:333). Isaiah's words in verses 18-20 against God's servant seem startling, though, if weighed against the earlier description of the servant in verses $1-4$. There the servant was portrayed as the one in whom God delights. How is it possible that the servant can be described in such contradictory terms? According to Beyer (2007:178), the answer can be found in the fluid nature of the term servant. In Isaiah 41:8, Israel, as the people of God, was designated as the servant, thus as a corporative personality, whilst in Isaiah 42:1-4, the servant is clearly portrayed as an individual. In the current passage, the term servant again portrays the corporate personality of Israel. Therefore, it is exilic Israel as a corporate personality that is being addressed as blind and deaf in verse 18 .

Now that Yahweh had Israel's attention in the exile where they were looking for real answers, God sent his prophet to verbally proclaim to them again who he is and what he is doing in order for them to interpret the history unfolding around them properly. Thereby they would be enabled to properly see the reason for the fall of the Israelite and Judean empires (Knight 1984:53). In this way, that which was foreseen in 29:18 and 35:5 happened. It is envisioned in these two verses that, in future, the blind will be able to see. The servant of the Lord effects this transformation by proclaiming the word of the Lord (Carroll 1997:88).

From the abovementioned it can be deduced that the reason why 'deaf' and 'blind' are used simultaneously is that Israel did not listen to what the prophets had told them about the reason for exile. Because they did not listen, they could not see how the righteousness of Yahweh required him to send his people into exile. With the use of 'hear you deaf' and 'look you blind' as a parallelism, attention is focused on the supplementary role the two concepts have on understanding one another. When the deaf start to hear, their blindness will cease. The same idea is also found in Isaiah 40:5, where it is said that the glory of the LORD will be revealed, and all mankind together will see it, for the mouth of the LORD has spoken. Thus, man will be able to see the glory of God, because he spoke (Leupold 1979:71).

From the divine perspective, hearing should therefore lead to seeing in such a way that you understand what you see. 
Without proper hearing, seeing is therefore not possible. Goldingay (2005:181) directs attention to the same situation in Deuteronomy:

With your own eyes you saw those great trials, those miraculous signs and great wonders. But to this day the LORD has not given you a mind that understands or eyes that see or ears that hear. (Dt 29:3-4)

As the people had seen many acts of God during their deliverance from Egypt, they have also seen many things during the reversal of the occupation of the land, but they did not heed in such a way that it gave rise to commitment to Yahweh (Bartholomew \& Goheen 2006:53).

Even though Israel, as servant of the Lord, was deaf and blind in the past, a turning point is announced in Isaiah 40:1. From then onwards they would be able to hear and therefore see. When the punishment that Yahweh brought over his people was recognised as his justness and faithfulness, hope would be encompassed. If they understood that the reason for the exile was chastisement from Yahweh, they would expect salvation by the same hand that had sent them into exile. The people of God should therefore understand, because they saw what they had heard beforehand.

Through his proclamation, Isaiah was to be the agent of Yahweh to open the deaf ears, and therefore the blind eyes of the people of God in order for them to see God's personal involvement in their lives. When the Word of God is truly heard and internalised, the deeds of God come into perspective, because hearing his Word leads to a renewed relationship with him. If the above is taken into account, it can be said that 'seeing' in exilic circumstances temporarily replaced 'hearing' in order for Yahweh to open the ears of his people because of what they had experienced.

\section{Isaiah 43:8-13}

The theme of Israel's blindness is picked up from Isaiah 42:18, but this time with a different perspective. The last of the 'blind deaf' combinations occurs in Isaiah 43:8, which is part of one of the 'trial scenes' - like those in Isaiah 41:1-5, 21-29; 44:6-8 and 45:20-25. In this judicial process, Yahweh puts himself up against the idols of the other nations in order for his people to reflect on the futile association they had with idols (Thompson 2001:38). The matter to be solved is found in Isaiah 43:9, where Yahweh challenges everybody to do the same things that he has done and pronounce beforehand what will come to pass - thereby showing himself to be the only and sovereign God.

Even though Israel is described as blind and deaf, they, as 'servant of the Lord', are brought before the court as witnesses. Israel should give testimony about the deeds of Yahweh in their history, but because of their spiritual blindness that was not possible. Therefore, God had to take responsibility for his own case (Motyer 1993:335). Even though Israel could not give testimony, they were a testimony because of their history, which was made possible by Yahweh. If it was not for the reality of God's action in the life of Israel, they would never have become a nation (Dt 7:6-9) and would have ceased to be one in exile (Is 6:13). No other god can lay claim to giving birth and sustaining a nation. Israel's history made that evident. By being able to do this, Yahweh alone can prove dominion over all history, thereby proving to be sovereign in his being (Childs 2001:335).

The presence of Israel in the heavenly court case, though, is not just for them to be witnesses for the sake of the other nations and their gods, but especially for their own sake. They were to witness anew that Yahweh is the only God, and that their hope and future lies with him alone. In the end, the trial is to build up their correct convictions about God, rather than to convince other people (Goldingay 2005:205).

The heavenly court case forced Israel to make a choice between Yahweh and the other gods. The present hour was to be the time of decision, because at that stage of Israel's history, they were no longer bound to a particular area of the earth's surface. Yet, even when Israel was not present in the Promised Land anymore, God was still present with them and he declared the things to come through his prophet (Westermann 1996:121). When God's people would realise how the prophecies he spoke through his prophets were fulfilled, new light would break through and their spiritual blindness would cease, because they heard what the sovereign God had said (Beyer 2007:179).

\section{Conclusion}

Isaiah was called to a people who continually transgressed the stipulations of the covenant despite the warnings of Yahweh's prophets. Consequently, they were exiled because of the righteousness of Yahweh. The way God's exiled people made sense of their situation, made it clear that they did not have the correct perspective regarding their punishment in accordance with the stipulations of the covenant, nor of their God or the history of themselves as a nation. The erroneous perspective they had was a result of their deliberate unwillingness to listen, which is described as deafness by Isaiah. Even though the stipulations of the covenant were proclaimed to them, they did not see the exile as a righteous act of Yahweh, but as him being indifferent to their situation. In a heavenly court of law, matters were set straight and it became clear that the reason why Israel could not see what was happening to them at the hand of Yahweh was because they did not listen to the prophets. Deafness therefore gave rise to blindness. The reason for the accumulation of the 'deaf blind' theme in such a small portion of Isaiah is because of the proceedings of the heavenly court of law, which commenced in Isaiah 1, being concluded in Isaiah 40-43.

\section{Acknowledgements Competing interests}

The author declares that he has no financial or personal relationship(s) that may have inappropriately influenced him in writing this article. 


\section{References}

Bartholomew, C. \& Goheen, M., 2006, The drama of Scripture, SPCK, London.

Balentine, S.E., 2011, 'The prose and poetry of exile', in B.E. Kelle, F.R. Ames \& J.L. Wright (eds.), Interpreting exile: Displacement and deportation in Biblical and modern contexts, pp. 345-364, Society of Biblical Literature, Atlanta.

Becking, B., 2011, 'A fragmented history of the exile', in B.E. Kelle, F.R. Ames \& J.L. Wright (eds.), Interpreting exile: Displacement and deportation in Biblical and modern contexts, pp. 151-169, Society of Biblical Literature, Atlanta.

Beyer, B.E., 2007, Encountering the book of Isaiah, Baker, Grand Rapids.

Block, D.I., 2011, How I love your Torah, o Lord! Studies in the book of Deuteronomy, Cascade, Eugene.

Brueggemann, W., 1997, Cadences of home: Preaching among exiles, Westminster John Knox, Louisville.

Carroll, R.P., 1997, 'Blindsight and the vision thing: Blindness and insight in the book of Isaiah', in C.C. Broyles \& C.A. Evans (eds.), Writing and reading the scroll of Isaiah: Studies of an interpretive tradition, vol. 1, pp. 79-93, Brill, Leiden.

Childs, B.S., 1983, Introduction to the Old Testament as Scripture, SCM, London.

Childs, B.S., 2001, Isaiah, Westminster John Knox, Louisville.

Clements, R.E., 1985, 'Beyond tradition-history: Deutero-Isaianic development of first Isaiah's themes', Journal for the study of the Old Testament (31), 95-113. http:// Ix.doi.org/10.1177/030908928501003106

Davidson, A.B., 1902, Introductory Hebrew grammar: Syntax, Clark, Edinburgh.

Dekker, J., 2012, 'Isaiah: Prophet in the service of the Holy One of Israel', in H.G.L. Peels \& S.D. Snyman (eds.), The Lion has roared, pp. 40-64, Pickwick, Eugene.

Evans, C.A., 1989, To see and not perceive: Isaiah 6:9, 10 in early Jewish and Christian interpretation, JSOT, Sheffield.
Goldingay, J., 2005, The message of Isaiah 40-55, Clark, London.

Harman, A., 2011, Isaiah: A covenant to be kept for the sake of the church, Christian Focus Publications, Geanies House.

Helberg, J.L., 2011, Die Here regeer, V\&R, Pretoria.

Hill, A.E., 2009, 'Deuteronomy', in A.E. Hill \& J. Walton (eds.), A survey of the Old Testament, pp. 163-178, Zondervan, Grand Rapids.

Jenni, E. \& Westermann, C., 1997, Theological lexicon of the Old Testament, Hendrickson, Peabody.

Kaiser, O., 1996, Isaiah 1-12: A commentary, SCM, London.

Knight, G.A.F., 1984, Servant theology: A commentary on the book of Isaiah 40-55, Eerdmans, Grand Rapids.

Leupold, H.C., 1979, Exposition of Isaiah, vol. 2, Baker, Grand Rapids.

Liedke, G., 1976, 'שפ' in W. Jenni \& C. Westermann (eds.), Theologisches Handwörterbuch zum Alten Testament, vol. 2, pp. 999-1010, Kaiser, München.

Matthews, V.H., 2012, The Hebrew prophets and their social world, Baker, Grand Rapids.

Merrill, E.H., 1994, Deuteronomy, Broadman \& Holman Publishers, Nashville.

Motyer, J.A., 1993, The prophecy of Isaiah, InterVarsity Press, Leicester.

Oswalt, J.N., 1986, The book of Isaiah: Chapters 1-39, Eerdmans, Grand Rapids.

Smith, G., 2009, Isaiah 40-66, Broadman \& Holman, Nashville.

Thompson, M.E.W., 2001, Isaiah: Chapters 40-66, Epworth, Peterborough.

Van der Walt, P.C., 2004, 'Die identiteit van God se volk in die boek Jesaja', PhDproefskrif, Fakulteit Teologie, Noordwes-Universiteit, Potchefstroom.

Westermann, C., 1996, Isaiah 40-66: A commentary, SCM, London.

Williamson, H.G.M., 2009, 'Recent issues in the study of Isaiah', in D.G. Firth \& H.G.M. Williamson (eds.), Interpreting Isaiah, pp. 21-37, Apollos, Nottingham. 